aureus strains with reduced susceptibility to vancomycin ${ }^{31-33}$ ). To avoid the rapid emergence of such strains, it is recommended that hospitals implement an antimicrobial audit and use program to prevent prolonged and sometimes unnecessary course of vancomycin therapy; enhance infection control programs to control multidrug-resistant organisms; and ensure that laboratories are testing staphylococci for vancomycin resistance, preferably by MIC methods, especially for isolates from sterile sites.

\section{REFERENCES}

1. Shulman JA, Nahmias AJ. Staphylococcal infection: clinical aspects. In: Cohen JO, ed. The Staphylococci. New York, NY: Wiley-Interscience; 1972:457-502.

2. Banerjee SN, Emori TG, Culver DH, Gaynes RP, Jarvis WR, Horan T, et al. Secular trends in nosocomial primary bloodstream infections in the United States, 1980-1989. National Nosocomial Infections Surveillance System. Am J Med 1991;91(3B):86S-89S

3. Schaberg DR, Culver DH, Gaynes RP. Major trends in the microbial etiology of nosocomial infection. Am J Med 1991;91(3B):72S-75S.

4. Emory TG, Gaynes RP. An overview of nosocomial infections, including the role of the microbiology laboratory. Clin Microbiol Rev 1993;6: 428-442.

5. Martin MA, Pfaller MA, Wenzel RP. Coagulase-negative staphylococcal bacteremia. Mortality and hospital stay. Ann Intern Med 1989;110:9-16.

6. Karchmer AW, Archer GL, Dismukes WE. Staphylococcus epidermidis causing prosthetic valve endocarditis: microbiologic and clinical observations as guide to therapy. Ann Intern Med 1983:98:447-455.

7. Archer GL, Tenenbaum MJ. Antibiotic resistant Staphylococcus epidermidis in patients undergoing cardiac surgery. Antimicrob Agents Chemother 1980;17:269-272.

8. Griffith RS. Vancomycin use-an historical review. I Antimicrob Chemother 1988;32:24-26.

9. Watanakunakorn C. In-vitro induction of resistance in coagulase-negative staphylococci to vancomycin and teicoplanin. $J$ Antimicrob Chemother 1988;22:321-324.

10. Hancock R, Fitz-James PC. Some differences in the action of penicillin, bacitracin, and vancomycin on Bacillus megaterium. I Bacteriol 1964;87:1044-1050.

11. Jordan DC, Inniss WE. Selective inhibition of ribonucleic acid synthesis in Staphylococcus aureus by vancomycin. Nature 1959;184:1894-1895.

12. Goldstein FW, Coutrot A, Sieffer A, Acar JF. Percentages and distributions of teicoplanin- and vancomycin-resistant strains among coagulasenegative staphylococci. Antimicrob Agents Chemother 1990;34:899-900.

13. Veach LA, Pfaller MA, Barrett M, Koontz FP, Wenzel RP. Vancomycin resistance in Staphylococcus haemolyticus causing colonization and bloodstream infection. I Clin Microbiol 1990;28:2064-2068.

14. Schwalbe RS, Stapleton JT, Gilligan PH. Emergence of vancomycin resistance in coagulase-negative staphylococci. $N$ Engl J Med 1987;316:927-931.

15. Schwalbe RS, Ritz WJ, Verma PR, Barranco EA, Gilligan PH. Selection for vancomycin resistance in clinical isolates of Staphylococcus haemolyticus. I Infect Dis 1990;161:45-51.
16. Tuazon CU, Miller $\mathrm{H}$. Clinical and microbiologic aspects of serious infections caused by Staphylococcus epidermidis. Scand I Infect Dis 1983;15:347-360.

17. Cherubin CE, Corrado ML, Sierra MF, Gombert ME, Shulman M. Susceptibility of gram-positive cocci to various antibiotics including cefotaxime, moxalactam, and N-formimidoyl thienamycin. Antimicrob Agents Chemother 1981;20:553-555.

18. Sanyal D, Johnson AP, George RC, Cookson BD, Williams AJ. Peritonitis due to vancomycin-resistant Staphylococcus epidermidis. Lancet 1991;337:54.

19. Krcmery V, Trupl J, Drgona L, Lacka J, Kukuckova E, Oravcova E. Nosocomial bacteremia due to vancomycin-resistant Staphylococcus epidermidis in four patients with cancer, neutropenia, and previous treatment with vancomycin. Eur I Clin Microbiol Infect Dis 1996;15:259-261.

20. Kloos WE, Bannerman TL. Staphylococcus and Micrococcus. In: Manual of Clinical Microbiology, 6th ed. Washington, DC: American Society for Microbiology; 1995:282-298.

21. National Committee for Clinical Laboratory Standards. Second Performance Standards for Antimicrobic Disk Susceptibility Tests. Approved standard MZ-A25. Villanova, PA: NCCLS; 1982.

22. Washington JA II, Sutter VL. Dilution susceptibility test: agar and macrobroth dilution procedures. In: Lennette EA, Ballows A, Hausler WJ Jr, Truant JP, eds. Manual of Clinical Microbiology. 3rd ed. Washington, DC: American Society for Microbiology; 1980:453-458.

23. National Committee for Clinical Laboratory Standards. Methods for Dilution Antimicrobial Susceptibility Tests for Bacteria That Grow Aerobically. 4th ed. Approved standard M7-A4. Wayne, PA: NCCLS; 1997.

24. National Committee for Clinical Laboratory Standards. Performance Standards for Antimicrobial Disk Susceptibility Tests. 6th ed. Approved standard M2-A6. Wayne, PA: NCCLS; 1997.

25. Clark NC, Cooksey RC, Hill BC, Swenson JM, Tenover FC. Characterization of glycopeptide-resistant enterococci from US hospitals. Antimicrob Agents Chemother 1993;37:2311-2317.

26. Satake S, Clark N, Rimland D, Nolte FS, Tenover FC. Detection of vancomycin-resistant enterococci in fecal samples by using the polymerase chain reaction. J Clin Microbiol 1997;35:2325-2330.

27. Bannerman TL, Hancock GA, Tenover FC, Miller JM. Pulsed-field gel electrophoresis as a replacement for bacteriophage typing of Staphylococcus aureus. J Clin Microbiol 1995;33:551-555.

28. Sattler FR, Foderano JB, Aber RC. Staphylococcus epidermidis bacteremia associated with vascular catheters: an important cause of febrile morbidity in hospitalized patients. Infect Control 1984;5:279-283.

29. Smith DJ, Kaplan RL, Landau W, Trenholme GM. Speciation and antibiotic susceptibility patterns of coagulase-negative staphylococci. Eur J Clin Microbiol 1982;1:228-232.

30. Swenson JM, Hill BC, Thornsberry C. Problems with the disk diffusion test for detection of vancomycin resistance in enterococci. $J$ Clin Microbiol 1989;27:2140-2142.

31. Centers for Disease Control and Prevention. Staphylococcus aureus with reduced susceptibility to vancomycin-United States, 1997. MMWR 1997;46:756-766

32. Centers for Disease Control and Prevention. Update: Staphylococcus aureus with reduced susceptibility to vancomycin-United States, 1997. MMWR 1997;46:813-815.

33. Smith TL, Pearson M, Tenover F, Jarvis WR. Emergence of vancomycin resistance in Staphylococcus aureus: epidemiology and clinical significance. $N$ Engl J Med. In press.

\title{
Continuing Education Credits Offered for CDC Reports
}

\section{Gina Pugliese, RN, MS Martin S. Favero, $\mathbf{P h D}$}

The $\mathrm{CDC}$ is offering continuing medical education (CME) and continuing nursing education (CNE) credits for selected reports and recommendations published in the Morbidity and
Mortality Weekly Report. To register and to receive credit, physicians and nurses must return their responses either electronically to the World Wide Web site (http://www.cdc.gov/epo/ mmwr/mmwr.html, then go to Continuing Education Program for Physicians and Nurses) or by mail. There is no fee for participating in this continuing edu- cation activity. $\mathrm{CME}$ and $\mathrm{CNE}$ components are planned for future $M M W R$ Recommendations and Reports.

FROM: Centers for Disease Control and Prevention. Notice to readers: availability of continuing medical education component in the $M M W R$ Recommen-dations and Reports series. MMWR 1998;47:912. 